\title{
EFFECT OF CLAY SOURCES ON REPRODUCTIVE PERFORMANCE OF DOE RABBITS FED AFLATOXICATED DIET
}

\author{
Samia Z. Meshreky, S.A. Z. Gad Alla, M. A. Abo Warda and Mervat M. Arafa
}

Animal Production Research Institute, Agricultural Research Center, Giza, Egypt.

\section{ABSTRACT}

A total of 60 female Bouscat rabbits at 10-12 months of age with an average body weight $3.48 \pm 0.11 \mathrm{~kg}$ were divided into three homogeneous groups $(n=20)$. The $1^{\text {st }}$ group was fed on a formulated pelleted diet as a control. The $2^{\text {nd }}$ and $3^{\text {rd }}$ groups were fed on the same diet replaced with 30 and $40 \%$ of diet naturally contaminated with $450 \mathrm{ppb}$ aflatoxins $\left(B_{1}+G_{1}\right.$, AF-diet), respectively. Each group was divided into two equal sub groups. The $1^{\text {st }}$ and $2^{\text {nd }}$ sub groups were fed on diet supplemented with $4 \mathrm{~g}$ of either tafla or bentonite clay/kg diet, respectively. Doe in each group was naturally mated with proven fertile buck after two weeks from start of treatments and continued for three consecutive parities.

Progesterone concentration at mid gestation period, litter size and litter weight at birth and at weaning, total milk yield from birth to 21 days of lactation and litter weight gain were reduced $(P<0.001$ or 0.01 or 0.05$)$ with increasing $A F$-diet intake and feeding duration time (from $1^{\text {st }}$ till $3^{\text {rd }}$ parities), while number of services per conception, abortion percentage and pre-weaning mortality rate tented to increase significantly. At $21^{\text {st }}$ day of pregnancy through $3^{\text {rd }}$ parity, body weight, ovaries weight, total embryos recovered, and maternal placenta weight decreased $(P<0.01$ or 0.05$)$ with increasing aflatoxin level in the diet. Moreover, lost embryos through pre-implantation and abnormal embryos percentages tended to increase significantly. Inclusion bentonite clay to the AFdiet reduced the harmful effect of aflatoxicosis and improved markedly reproductive performance, litter traits, milk production and embryo quality compared to tafla supplementation, especially with increasing feeding duration. Genitalia organs were adversely affected by aflatoxins consumed, especially with elevating AF-diet. Does fed 30\% AF-diet+bentonite showing normal genitalia appearance than that fed the same diet+tafla. Liver and kidneys of doe rabbits fed $40 \%$ AF-diet+tafla showed more deterioration than that fed $30 \%$ AF-diet+tafla or 30 and 40\% AF-diet+bentonite. Generally, inclusion $4 \mathrm{~g}$ bentonite clay $/ \mathrm{kg}$ diet protect mature doe rabbits fed diet contaminated with 135 ppb aflatoxins + without retardation in the reproductive performance.

Key words: Aflatoxins, bentonite, tafla clay, doe rabbits, reproductive performance. 


\section{INTRODUCTION}

Pollution of air, feed and water represent great problem for each of human and animals. Pollution of feed animal with aflatoxins represents great economical losses resulting from decreasing animal performance (Bueno \& Oliver, 2004 and Groopman $\&$ Kensler, 2005) and death induced from ingestion of toxic material (Harvey et al., 1993). Aflatoxins are fungal metabolites produced by different Aspergillus species, which B1 is the most frequently found in contaminated feed samples. Aflatoxins are considered carcinogenic. Both the potency and carcinogenicity are dependent on the species, dose and duration of intake, age of animal and nutritional state (Diekman and Green, 1992).

Controlling the effect of mycotoxin contaminated feeds may represent a great hope for decreasing toxicity and minimizing hazards effect. Nowar et al. (2001), Abd El-Baki et al. (2002), Schatzmayr et al. (2006) and Meshreky et al. (2007) succeeded in using clay minerals (bentonites, tafla and zeolites) for detoxification and controlling toxicity of aflatoxins contaminated feeds, suggesting that detoxification natural clays would adsorb toxic products of digestion and decrease accumulation of toxic substance in tissues (Harvey et al., 1993 and Elmore, 2003).

The aim of the present study is to define the effects of aflatoxine levels in the rabbit diets (AF-diet) and source of natural clay as a detoxifying agent in the prevention of toxic effects of aflatoxins on reproductive performance of doe Bouscat rabbits during three consecutive parities.

\section{MATERIALS AND METHODS}

The present study was carried out in the Rabbitry of EL-Gemmeza Research Station, EL-Gharbiya Governorate, Animal Production Research Institute, Agricultural Research Center, Ministry of Agriculture, Egypt.

A total of 60 female Bouscat rabbits at 10-12 months of age with an average body weight $3.48 \pm 0.11 \mathrm{Kg}$ were used. Animals were divided into three equal homogeneous groups $(\mathrm{n}=20)$. The $1^{\text {st }}$ group was fed on a formulated pelleted diet as a control $(25.0 \%$ yellow corn, $25.0 \%$ soya bean meal, $22 \%$ wheat bran, $15.0 \%$ berseem hay, $8.4 \%$ berseem straw, $0.3 \%$ common salt, $0.3 \%$ premix, $3 \%$ molasses and $1.0 \%$ limestone) containing $18.13 \%$ crude protein, $2.69 \%$ fat and $12.7 \%$ fibers according to NRC (1984). The $2^{\text {nd }}$ and $3^{\text {rd }}$ groups were fed on the same diet replaced with 30 and $40 \%$ of diet naturally contaminated with $450 \mathrm{ppb}$ aflatoxins $\left(\mathrm{B}_{1}+\mathrm{G}_{1}\right.$, AF-diet), respectively. Each group was divided into two equal subgroups. The $1^{\text {st }}$ and $2^{\text {nd }}$ subgroups were fed the diet supplemented with $4 \mathrm{~g}$ tafla or bentonite clay/kg diet, respectively. Such natural clay (Manganes Sinai Company, Kasser El-Nile Street, Cairo) contained: 52.0\% $\mathrm{SiO}_{2}$, $22 \% \mathrm{Al}_{2} \mathrm{O}_{3}, 3.5 \% \mathrm{Fe}_{2} \mathrm{O}_{3}, 2.3 \% \mathrm{Na}_{2} \mathrm{O}, 3.0 \% \mathrm{CaO}, 1.6 \% \mathrm{MgO}, 1.7 \% \mathrm{~K}_{2} \mathrm{O}, 10.0 \%$ moisture content $\left(110^{\circ} \mathrm{C}\right)$, Surface area $\left(\mathrm{m}^{2} / \mathrm{g}\right)$ of raw ore for tafla clay and $50-55 \%$ $\mathrm{SiO}_{2}, 18-22 \% \mathrm{Al}_{2} \mathrm{O}_{3}, 3-5 \% \mathrm{Fe}_{2} \mathrm{O}_{3}, 2.0-3.2 \% \mathrm{Na}_{2} \mathrm{O}, 0.1-0.3 \mathrm{CaO}, 0.5-1.6 \% \mathrm{MgO}, 1.2-$ $2.2 \mathrm{k}_{2} \mathrm{O}, 8-14$ L.O.I, 10.0 max\% moisture content $\left(110^{\circ} \mathrm{C}\right)$, Surface area $\left(\mathrm{m}^{2} / \mathrm{g}\right)$ of raw ore for bentonite clay. 
Rabbits were individually housed in galvanized wire cages. Stainless steel drinking nipples and feeders were supplied for each cage. Feed and water were offered $a d$ libitum. Animals were kept under similar managerial conditions. Each doe was naturally mated with proven fertile buck after two weeks of treatments and continued for three consecutive parities. On the twelve day after mating, each mated doe was abdominally palpated to detect pregnancy. After 5-7 days of kindling, does were mated. At 3-4 days before the expected day of parturition nest box was placed in the cage and for 28 days following parturition. Number of services per conception (NSC), abortion percentage $(\mathrm{Ab})$, gestation length $(\mathrm{GL})$, litter size and litter weight $(\mathrm{g})$ at birth and at weaning (28 days), bunny weight at birth and at weaning, litter weight gain and preweaning mortality percentage, were recorded.

Milk yield (g) of each doe was recorded at the seventh, $14^{\text {th }}$ and $21^{\text {st }}$ days after kindling, using the weight-suckle-weight technique described by McNitt and Lukefahr (1990). Total milk yield (TMY) of the first 21 days of the suckling period was considered as seven times of the sum of milk yield at $7^{\text {th }}, 14^{\text {th }}$ and $21^{\text {st }}$. Daily milk intake of young (DMI) in grams was recorded. Milk to litter conversion ratio (MC) during the first 21 days of lactation period was calculated (total milk yield /litter weight gain from birth to 21 days).

Five blood samples were collected from marginal ear vein of rabbits using heparinized tubes at mid day of gestation (day 15) of each treatment in each parity, centrifuged at $3000 \mathrm{rpm}$ for 15 minutes. Plasma was separated and stored at $-20{ }^{\circ} \mathrm{C}$ till analysis. Progesterone $\left(\mathrm{P}_{4}\right)$ concentration was determined by using RIA kit (Diagnostic Systems Laboratories, Inc., USA) according to the manufacturer information.

On day 21 of pregnancy in the $3^{\text {rd }}$ parity, three rabbits from each treatment were chosen and slaughtered to study some phenomenal embryos and histopathological parameters of the genitalia, liver and kidneys. Tissue samples from such organs were taken and fixed in Boun's solution, then processed by standard technique and stained with haematexylin and Eosin (Bancroft and Cook, 1994).

Data were analyzed using GLM procedure in $\operatorname{SAS}^{\circledR}(1996)$ program and the differences among means were tested using Duncan's New Multiple Range Test (Duncan, 1955). Data estimated in percentage were transformed with the arcsine square-root procedure to normalize variance before analysis and were retransformed again to the original scale before presentation.

\section{RESULTS AND DISCUSSION}

\section{Progesterone hormone $\left(P_{4}\right)$ level:}

Progesterone concentration $\left(\mathrm{P}_{4}\right)$ at mid gestation of Bouscat rabbits was reduced $(\mathrm{P}<0.01$ or 0.05$)$ with increasing AF-diet consumed and feeding duration time (Figure 1). These may be due to aflatoxicosis effects, indirect effect of aflatoxins that leads to fluctuations in LH level, which has a primary stimulating effect on $\mathrm{P}_{4}$ secretion in domestic animals, and/or a reduction rate of embryo survival (Parr et al., 1982). Mills and Stopper (1989) stated that plasma progesterone concentrations 
during pregnancy are related to the number of corpora lutea, their synthesis and secretion. Inclusion of bentonite clay to the AF-diet was more effective in reduction of the harmful effect of aflatoxicosis compared with tafla supplementation (Figure 1). Progesterone level was higher $(\mathrm{P}<0.05)$ in does fed basal diet without aflatoxins with bentonite clay than in that fed the same diet supplemented with tafla clay.

\section{Reproductive and litter traits:}

Number of services per conception (NSC), abortion (Ab) percentage and preweaning mortality rate increased $(\mathrm{P}<0.001,0.01$ or 0.05$)$ by increasing AF-diet consumed and feeding duration, while litter size and litter weight at birth and at weaning, and litter weight gain tented to decreased (Table 1). The same finding was observed by Meshreky et al. (2007) who found that aflatoxins reduced significantly oestrogen level, receptivity and subsequently conception rate of female rabbits. In addition, Cheeke and Shull (1985) reported that the mechanism by which aflatoxin reduce growth rate is probably related to disturbances in protein, charbohydrate and lipid metabolism. The increase stillborn and pre-weaning mortality rate with increasing AF-diet and advancement of parity (Table1) might be due to the penetrated aflatoxin through the alimentary system and blood for milk synthesis in alveolar cells of the mammary gland (Veldman et al., 1992) and the direct effect of aflatoxicosis on the sensitive young offspring during suckling and with start eating from feeder (18 day old). Ferrufino et al. (2000) found a linear relationship between the ochratoxin A concentrations in milk of rabbit does fed a naturally-contaminated feed and in the plasma of the sucklings, indicating an effective transfer of the toxin to the sucklings. Moreover, Fernandez et al. (1997) stated that aflatoxin caused a failure in the acquired immunity system by decreasing antibody production and reduced serum protein, which may be due to changes in hormonal balance.

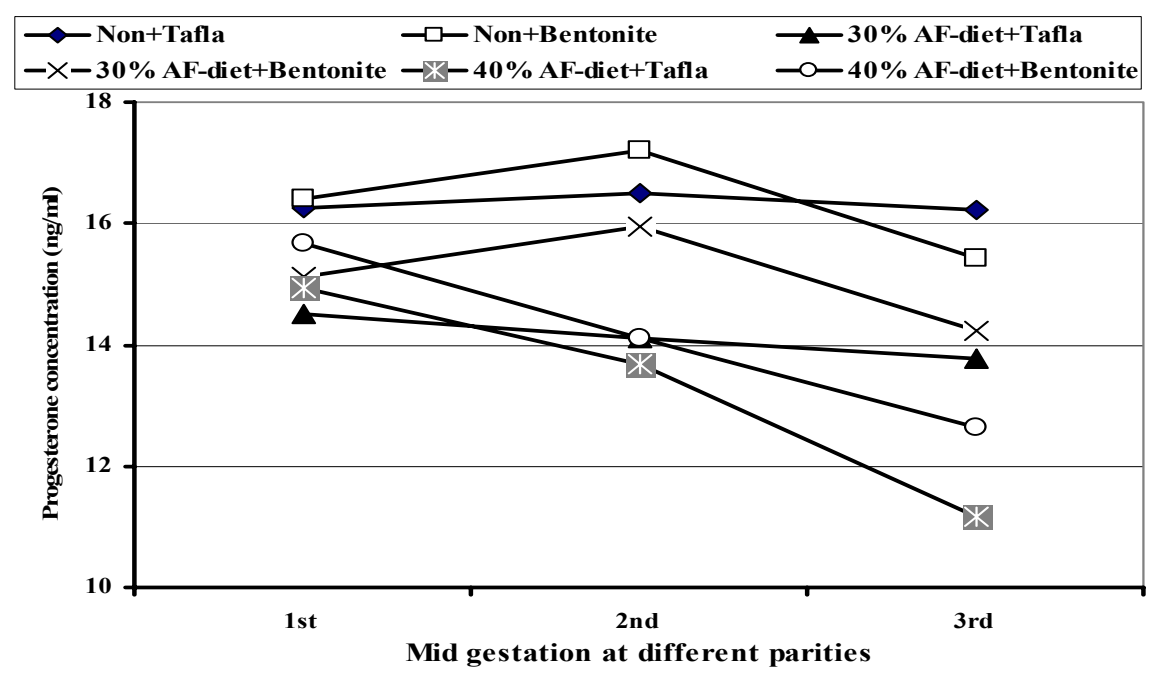

Figure 1. Progesterone levels $(\mathrm{ng} / \mathrm{ml})$ at mid gestation period as affected by dietary aflatoxins contaminated diet (AF-diet) and type of detoxifying agents. 
Table 1. Reproductive traits of female Bouscat rabbits through three parities as affected with aflatoxin contaminated and detoxified rations.

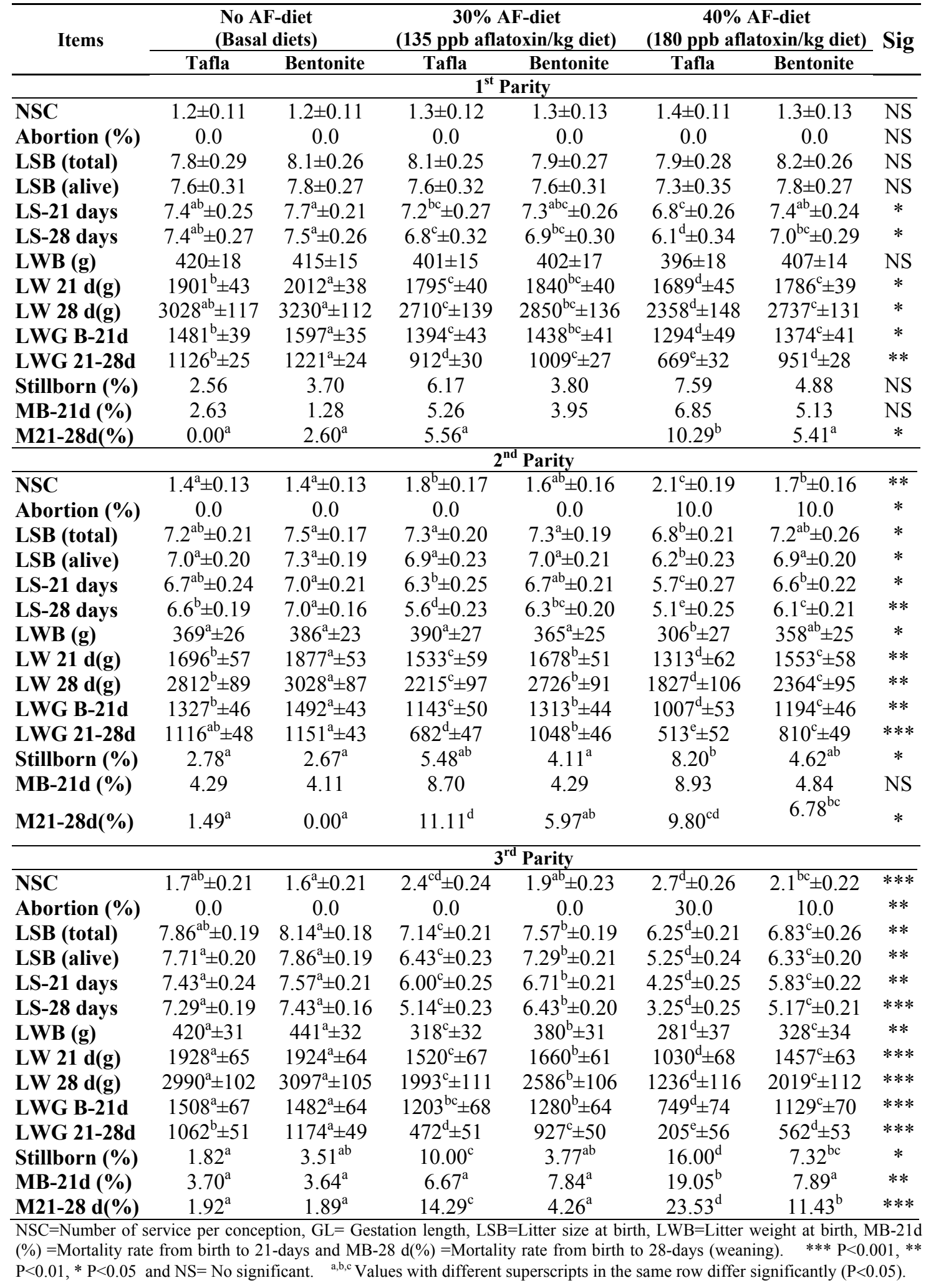


The highest values of litter size and weight and the lowest NSC and preweaning mortality were estimated in does rabbits fed basal diet without aflatoxins supplemented with bentonite or tafla clay groups compared with other groups (Table 1). Addition of bentonite clay to the AF-diet reduced the harmful effect of aflatoxicosis more than tafla supplementation, especially with increasing feeding duration. Similar to that reported by Harvey et al. (1993) who found that aluminosilicate compounds (natural clay) are able to protect chickens, swine, and lambs from the deleterious toxic effects of $\mathrm{AF}$ and to reduce AF residues in milk of dairy cows and goats. In this respect, Veldman et al. (1992) revealed that AF content in milk was significantly reduced with bentonite supplementation. Ramos and Fernandez (1993) demonstrated that bentonite at $1 \%$ adsorbed nearly $100 \%$ of the existing 5 ppm $\mathrm{AFB}_{1}$ in a simulated intestinal fluid of cows.

\section{Milk yield, milk intake and milk conversion ratio:}

Total milk yield from birth to 21 days of lactation decreased ( $\mathrm{P}<0.001,0.01$ or 0.05) in does fed AF-diet (Table 2). The differences among treatments in milk yield and subsequently daily milk intake of their young may be related to differences in number of young's at birth (Zerrouki et al., 2002), as well as, differences in amount of aflatoxins intake and long period of aflatoxins hazard. Amin et al. (1991) observed increased fibrosis and collagen deposition with thick-walled blood vessels in mammary gland of Bouscat rabbits received aflatoxin B1 $(50 \mu \mathrm{g} / \mathrm{kg}$ body weight) during pregnancy and lactation. These changes may be the cause of decreased secretion of milk inside the alveoli. Similarly, in ewes (Hassan, 2003) and in lambs (Soliman et al., 2005) found AF in diet decreases the milk yield. In addition, Applebaum et al. (1981) showed that $8 \%$ decrease in milk production of cows fed diet containing $1 \mathrm{ppm}$ AF after six weeks; moreover cows fed a diet containing $4 \mathrm{ppm} \mathrm{AF}$ given the same decrease in production, but only after two weeks on the diet. Addition of bentonite clay to the basal diet or AF-diet increased significantly milk yield compared with those fed the same diet with tafla (Table 2). Inclusion bentonite clay to the AF-diet enhanced significantly milk conversion ratio than tafla clay during $3^{\text {rd }}$ parity (Table 2).

\section{Body weight and some ovarian and embryos measurements:}

Body weight $(\mathrm{Kg})$, ovaries weights $(\mathrm{g})$, total embryos recovered and placental weight $(\mathrm{g})$ decreased $(\mathrm{P}<0.01$ or 0.05$)$ with increasing aflatoxin in the diet, whereas, lost embryos during pre-implantation and abnormal embryos percentages tended to increase significantly (Table 3 and Pate 1). These results are in harmony with results obtained by Diekman and Green (1992) who mentioned that the potency of aflatoxins is dependent on the dose of intake, duration of intake, age of animal and nutritional state. Also, Badawy (1997) reported that the presence of implantation sites in the uterine horns of rabbits fed aflatoxin diet after mating or during mid-pregnancy indicated early fetal resorption. Results in Table (3) and Plate (1) revealed that addition bentonite to 30 or $40 \%$ AF-diet reducing the detrimental effects of aflatoxin more than that fed the same diet supplemented with tafla. 
Table 2. Total milk yield (TMY) of doe rabbit (g), daily milk intake of young (DMI, g) and milk conversion ratio (MC) as affected by dietary aflatoxins contaminated diet (AF-diet) and type detoxifying agents.

\begin{tabular}{|c|c|c|c|c|c|c|c|}
\hline \multirow[t]{2}{*}{ Items } & \multicolumn{2}{|c|}{$\begin{array}{l}\text { No AF-diet } \\
\text { (Basal diet) }\end{array}$} & \multicolumn{2}{|c|}{$\begin{array}{c}30 \% \text { AF-diet } \\
\text { (135 ppb aflatoxin/kg diet) }\end{array}$} & \multicolumn{2}{|c|}{$\begin{array}{c}40 \% \text { AF-diet } \\
\text { (180 ppb aflatoxin/kg diet) }\end{array}$} & \multirow[t]{2}{*}{ Sig. } \\
\hline & Tafla & Bentonite & Tafla & Bentonite & Tafla & Bentonite & \\
\hline \multicolumn{8}{|c|}{$1^{\text {st }}$ Parity } \\
\hline TMY & $2595.9^{\mathrm{ab}} \pm 93$ & $2772.8^{\mathrm{a}} \pm 93$ & $2593.3^{\mathrm{ab}} \pm 93$ & $2600.4^{\mathrm{ab}} \pm 93$ & $2387.1^{b} \pm 93$ & $2615.5^{\mathrm{ab}} \pm 93$ & $*$ \\
\hline DMI & $16.83 \pm 0.59$ & $17.38 \pm 0.59$ & $17.30 \pm 0.59$ & $17.46 \pm 0.59$ & $16.77 \pm 0.59$ & $16.91 \pm 0.59$ & NS \\
\hline MC & $1.75^{\mathrm{a}} \pm 0.031$ & $1.74^{\mathrm{a}} \pm 0.031$ & $1.86^{\mathrm{b}} \pm 0.031$ & $1.81^{\mathrm{ab}} \pm 0.031$ & $1.84^{\mathrm{ab}} \pm 0.031$ & $1.91^{\mathrm{b}} \pm 0.031$ & ** \\
\hline \multicolumn{8}{|c|}{$2^{\text {nd }}$ Parity } \\
\hline TMY & $2444.9^{\mathrm{b}} \pm 97$ & $2758.2^{\mathrm{a}} \pm 97$ & $2107.8^{c} \pm 97$ & $2427.9^{b} \pm 97$ & $2012.5^{\mathrm{c}} \pm 108$ & $2199.6^{\mathrm{bc}} \pm 108$ & $* *$ \\
\hline DMI & $17.25 \pm 0.92$ & $18.90 \pm 0.92$ & $15.82 \pm 0.92$ & $17.44 \pm 0.92$ & $16.74 \pm 1.03$ & $16.57 \pm 1.03$ & NS \\
\hline MC & $1.84 \pm 0.039$ & $1.85 \pm 0.039$ & $1.84 \pm 0.039$ & $185 \pm 0.039$ & $1.95 \pm 0.043$ & $1.83 \pm 0.043$ & NS \\
\hline \multicolumn{8}{|c|}{$\mathbf{3}^{\text {rd }}$ Parity } \\
\hline TMY & $2801.9^{\mathrm{a}} \pm 107$ & $2838.7^{a} \pm 107$ & $2242.3^{b} \pm 107$ & $2335.4^{b} \pm 107$ & $1637.2^{c} \pm 139$ & $2114.7^{b} \pm 121$ & $* * *$ \\
\hline DMI & $18.50 \pm 0.83$ & $17.97 \pm 0.83$ & $17.88 \pm 0.83$ & $16.44 \pm 0.83$ & $16.92 \pm 1.07$ & $17.77 \pm 0.93$ & NS \\
\hline MC & $1.86^{\mathrm{a}} \pm 0.043$ & $1.92^{\mathrm{ab}} \pm 0.043$ & $1.86^{\mathrm{a}} \pm 0.043$ & $1.82^{\mathrm{a}} \pm 0.043$ & $2.01^{\mathrm{b}} \pm 0.056$ & $1.87^{\mathrm{a}} \pm 0.048$ & $*$ \\
\hline
\end{tabular}

Table 3. Body weight $(\mathrm{Kg})$ and some ovarian and embryo measurements of female Bouscat rabbits at day-21 of pregnancy through the $3^{\text {rd }}$ parity as affected with aflatoxin contaminated and detoxified rations.

\begin{tabular}{|c|c|c|c|c|c|c|c|}
\hline \multirow[t]{2}{*}{ Items } & \multicolumn{2}{|c|}{$\begin{array}{l}\text { No AF-diet } \\
\text { (Basal diets) }\end{array}$} & \multicolumn{2}{|c|}{$\begin{array}{c}30 \% \text { AF-diet } \\
\text { (135 ppb aflatoxin/kg diet }\end{array}$} & \multicolumn{2}{|c|}{$\begin{array}{c}40 \% \text { AF-diet } \\
(180 \mathrm{ppb} \text { aflatoxin } / \mathrm{kg} \\
\text { diet) }\end{array}$} & \multirow[t]{2}{*}{ Sig } \\
\hline & Tafla & Bentonite & Tafla & Bentonite & Tafla & Bentonite & \\
\hline$\overline{\text { Body }}$ & $3.97^{\mathrm{ab}} \pm .05$ & $4.06^{\mathrm{a}} \pm 0.05$ & $3.68^{\mathrm{c}} \pm 0.05$ & $3.88^{\mathrm{b}} \pm 0.05$ & $3.46^{\mathrm{d}} \pm 0.05$ & $3.63^{\mathrm{cd}} \pm .05$ & $* *$ \\
\hline Ovaries weight(g) & $1.18^{\mathrm{ab}} \pm .06$ & $1.25^{\mathrm{a}} \pm 0.06$ & $1.08^{\mathrm{bc}} \pm .06$ & $1.11^{\mathrm{ab}} \pm .06$ & $0.85^{c} \pm 0.06$ & $0.99^{\mathrm{bc}} \pm .06$ & $* *$ \\
\hline No. $C L$ & $8.33 \pm 0.7$ & $8.67 \pm 0.7$ & $7.67 \pm 0.7$ & $8.67 \pm 0.7$ & $7.33 \pm 0.7$ & $7.33 \pm 0.7$ & NS \\
\hline Total embryos & $8.00^{\mathrm{a}} \pm 0.6$ & $8.33^{\mathrm{a}} \pm 0.6$ & $6.67^{\mathrm{b}} \pm 0.6$ & $8.00^{\mathrm{a}} \pm 0.6$ & $6.00^{\mathrm{b}} \pm 0.6$ & $6.33^{b} \pm 0.6$ & * \\
\hline LEPI (\%) & $3.70^{\mathrm{a}}$ & $4.17^{\mathrm{a}}$ & $13.23^{\mathrm{b}} \mathrm{c}$ & $7.04^{\mathrm{ab}}$ & $17.86^{\mathrm{c}}$ & $12.17^{\mathrm{bc}}$ & * \\
\hline Ab. Emb. (\%) & $4.17^{\mathrm{a}}$ & $3.03^{\mathrm{a}}$ & $8.33^{\mathrm{ab}}$ & $7.41^{\mathrm{a}}$ & $25.40^{\mathrm{c}}$ & $15.08^{\mathrm{b}}$ & $*$ \\
\hline Embryo weight & $14.04^{\mathrm{a}} \pm .26$ & $13.74^{\mathrm{a}} \pm .24$ & $13.80^{\mathrm{a}} \pm .31$ & $13.62^{\mathrm{a}} \pm .26$ & $9.15^{\mathrm{c}} \pm .34$ & $11.40^{\mathrm{b}} \pm .33$ & $* *$ \\
\hline PW (g) & $3.26^{\mathrm{ab}} \pm .12$ & $3.05^{\mathrm{ab}} \pm .11$ & $3.47^{\mathrm{a}} \pm .15$ & $3.16^{\mathrm{ab}} \pm 11$ & $2.28^{\mathrm{c}} \pm .17$ & $2.72^{\mathrm{b}} \pm .16$ & $*$ \\
\hline
\end{tabular}

No. $\mathrm{CL}=$ Number of corpora lutea, LEPI $=$ Lost embryos pre-implantation percentage, $\mathrm{Ab}$. Emb. $=$ Abnormal embryos percentage and $\mathrm{PW}=$ Placental weight.

${ }^{a, b, c}$ Values with different superscripts in the same column differ significantly $(\mathrm{P}<0.05)$.

${ }^{* * *} \mathrm{P}<0.001,{ }^{* *} \mathrm{P}<0.01,{ }^{*} \mathrm{P}<0.05$ and $\mathrm{NS}=$ Not significant. 


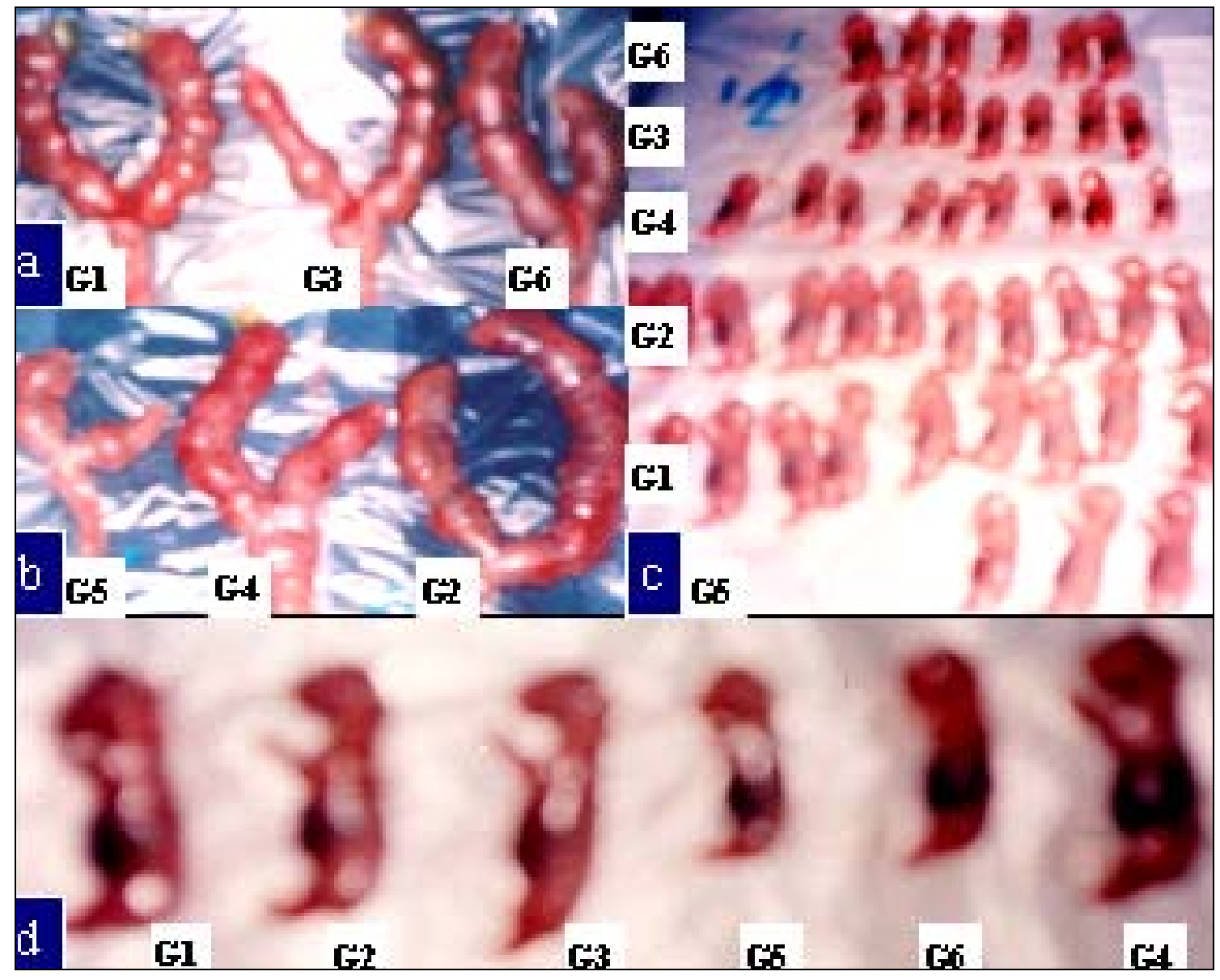

Plate 1. (a \& b) Showing uterus of doe rabbits with resorption sites in $5^{\text {th }}$ (fed diet with $180 \mathrm{ppb}$ aflatoxin+tafla) and $6^{\text {th }}$ (fed diet with $180 \mathrm{ppb}$ aflatoxin+bentonite) groups, whereas in the $1^{\text {st }}$ (fed diet without aflatoxin +tafla), $2^{\text {nd }}$ (fed diet without aflatoxin + bentonite), $3^{\text {rd }}$ (fed diet with $135 \mathrm{ppb}$ aflatoxin+tafla) and $4^{\text {th }}$ (fed diet with $135 \mathrm{ppb}$ aflatoxin+bentonite) groups showing normal uterus without resorption sites. (c) Embryo recovered from different treated groups: showing retardation of growth in rabbit fetuses recovered from dam fed diets with different levels of aflatoxin+tafla or bentonite clay (G3, G4, G5 and G6) compared with that fed diet without aflatoxin+tafla or bentonite clay (G1 and G2). (d) Showing abnormality and retardation growth in rabbit fetuses recovered from dam in G3, G5 and G6.

\section{Histopathological examination:}

\section{Genitalia organs:}

Ovarian of rabbits fed free diet+bentonite or tafla, showed large numbers of Graafian follicles and their uterus showed more number and activity of uterine glands, these numbers were more pronounced than that on ovaries of does fed diet with aflatoxin (Plate 2). Ovaries of rabbits fed $40 \%$ AF-diet+tafla showed presence of few numbers of mature follicles with secondary follicles than that of rabbits fed $30 \% \mathrm{AF}$ diet+tafla, which showed several follicles in different stages of maturity and few 

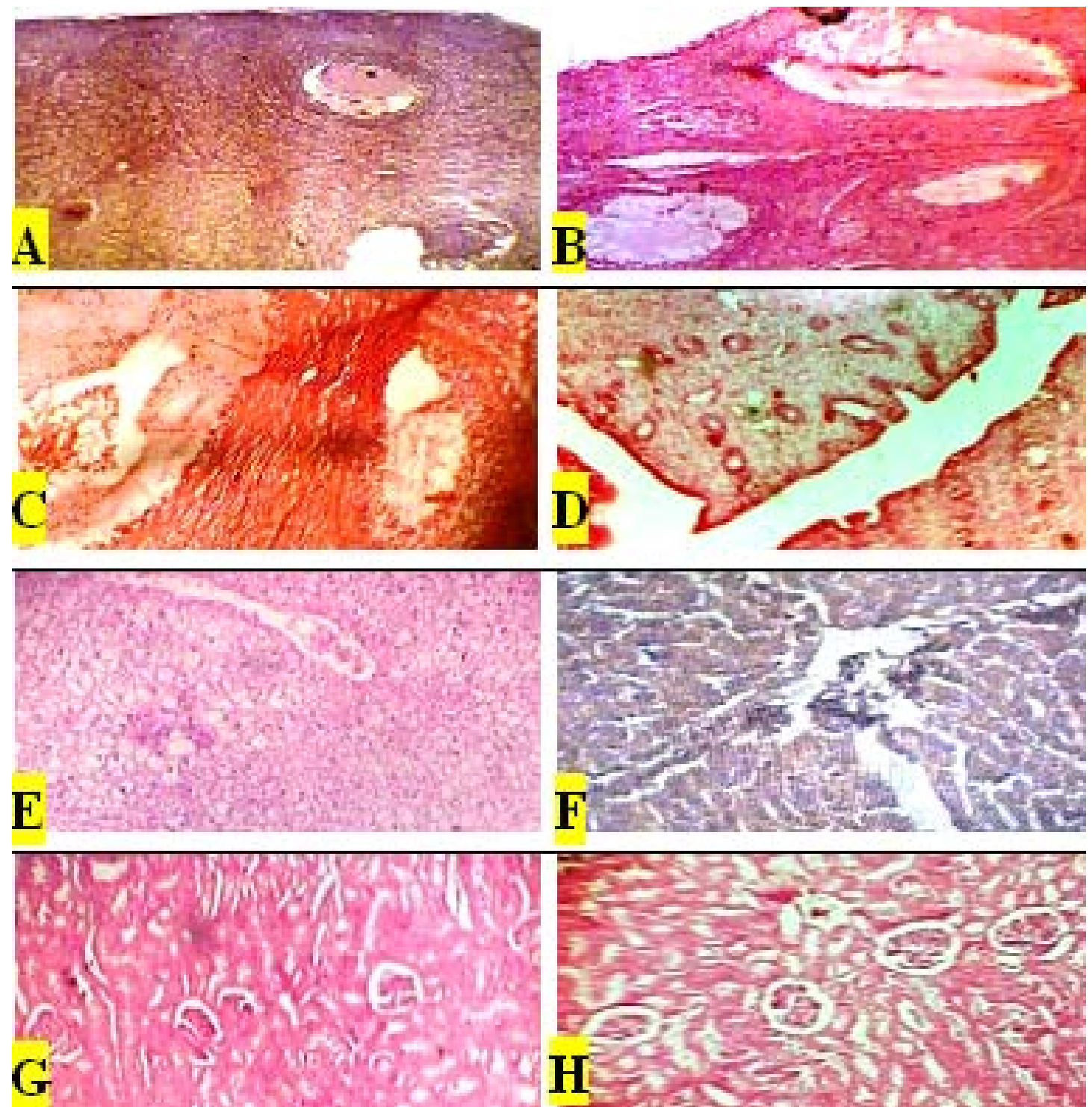

Plate 2. Cross sections in (A) Ovary of doe rabbits fed 40\%AF-diet+tafla, showing higher interstitial tissue and low number of mature follicles (H \& E x33). (B) Ovary of does fed 30\%AF-diet+bentonite, showing increase in number of mature follicle $(\mathrm{H} \& \mathrm{E}$ x33). (C) Ovary of doe rabbits fed free diet+tafla, showing presence of high number of mature follicles in the cortex ( $\mathrm{H} \& \mathrm{E} \times 33)$. (D) Uterus of does fed $30 \% \mathrm{AF}$ diet + tafla, showing few numbers in the uterine glands (H \& E x66). (E) Liver of doe rabbit fed the $30 \% \mathrm{AF}$ diet+bentonite showing normal architecture of the hepatic lobules, central vein and hepatocytes as well as the portal lobules (x100, H\&E stains). (F) Liver of doe rabbit fed $40 \% \mathrm{AF}$ diet+tafla showing abnormal hepatocytes and high amount of red blood cells in the central vein (x150, H\&E stains). (G) Kidneys of doe rabbit fed 30\%AF diet+tafla showing apparently normal architecture of the renal cortex with neoplastic signs and periglomerular and peritubular cell infiltration (x150, H\&E stains). (H) Kidneys of doe rabbits fed free diet+bentonite showing normal architecture of the renal cortex and intact structure of both glomerulosa and renal tubules (x150, H\&E stains). 
numbers of follicles degenerated. However, ovary of does fed $30 \%$ AF-diet+bentonite showed mature follicles in addition to presence of atretic follicles than that fed 30 or $40 \%$ AF-diet+tafla. Uterus of does fed 30\%AF-diet+tafla, proved few numbers of uterine glands, meanwhile, uterus of does fed 40\%AF-diet+bentonit, had more number and great activity of uterine glands. These results agreed with those observed by Badawy (1997) who found severe pathological changes in the ovaries and uterus of rabbits fed AF-diet compared with control group.

\section{Liver and kidneys:}

Liver and kidneys of doe rabbits fed $40 \%$ AF-diet+tafla were clearly changed in compared with that fed diet without aflatoxin (Plate 2). These finding agreed with that observed by Soliman et al. (2001) who found particularly alteration in liver and kidneys of rabbits fed AF-contaminated diet ( $833 \mu \mathrm{g}$ of aflatoxins $/ \mathrm{kg}$ ). Winston and Hagler (1988) also found that $\mathrm{AFB}_{1}$ caused noticeable damage in liver. Rrabbits fed $40 \%$ AF-diet+tafla showed deterioration in liver and kidneys structures more than that fed $30 \%$ AF-diet+tafla. Addition bentonite to rabbits fed diet with 30 or $40 \%$ AF-diet reducing the detrimental effects of aflatoxin more than that fed the same diet supplemented with tafla.

\section{CONCLUSION}

1. Elevating aflatoxins ratio in the diet and increasing its consumption period adversely affected progesterone and genitalia organs and consequently declined the reproductive performance, litter traits and milk production of Bouscat doe rabbits

2. Bentonite clay in the rabbit diet would relive the harmful effects of aflatoxicosis and consequently improved their reproductive performance markedly than tafla clay.

\section{REFERENCES}

Abd El-Baki, S.M., Nowar, M.S., Hassona, E.A., Bassuny, S.M. and Shehata, S.A. (2002). Clays in animal nutrition:10. detoxification of aflatoxin $B_{1}$ by tafla clay in rabbit feeds. $3{ }^{\text {rd }}$ Science Conference On Rabbit Production in Hot Climates, Egypt, 8-11 Oct:557-567.

Amin, S.O., Abdel-Aal, W.E., El-Fouly, M.A., Abdel-Wahhab, M.A. and Naguib, K. (1991). Aflatoxicosis in rabbits. 1. Histopathological and histochemical study of mammary gland during pregnancy and lactation as affected by aflatoxin B1 administration. Egyptian Journal of Animal Production, 28: 2, 179-189.

Applebaum, R.S., Brackett, R.E., Wiseman, D.W. and Marth, E. H. (1981). Response of dairy cows to dietary aflatoxin feed intake and yield, toxin content, and quality of milk of cows treated with pure and impure aflatoxin. Journal of Dairy Science, 65: 1503-1508. 
Badawy, S.A. (1997). Studies on pregnancy failure in rabbits possibly due to aflatoxicosis. Veterinary Medical Journal, Giza, 45: 3, 403-417.

Bancroft, D.J. and Cook, C.H. (1994). Manual of Histological Techniques and Their Diagnostic Application. 3 rd Edition, Churchill, Livingston and Edinburg.

Bueno, D.J. and Oliver, G. (2004). Determination of aflatoxins and zearalenone in different culture media. Methods Mol Biol., 268:133-137.

Cheeke, P.R. and Shull, L.R. (1985). Natural Toxicants in Feed and Poisonous Plants. AVA-Van Nostrand-Reinold, New York.

Diekman, M.A. and Green, M.L. (1992). Mycotoxins and reproduction in domestic livestock. Journal of Animal Science, 70: 1615-1627.

Duncan, D. B. (1955). Multiple range and multiple F. test. Biometrics, 11: 1-42.

Elmore, A.R. (2003). Final report on the safety assessment of aluminum silicate, calcium silicate, magnesium aluminum silicate, magnesium silicate, magnesium trisilicate, sodium magnesium silicate, zirconium silicate, attapulgite, tafla, Fuller's earth, hectorite, kaolin, lithium magnesium silicate, lithium magnesium sodium silicate, montmorillonite, pyrophyllite and zeolite. International Journal of Toxicology,,22( Suppl.) 1:37-102.

Fernandez, A., Hernandez, M., Sanz, M., Verde, M.T. and Ramos, J. (1997). Serological serum protein fraction and responses to Brucella melitensis in lambs fed aflatoxins. Vetrinary and Human Toxicology, 39:137.

Ferrufino, G.E.V., Tangni, E.K., Larondelle, Y. and Ponchaut, S. (2000). Transfer of ochratoxin A during lactation: exposure of suckling via the milk of rabbit does fed a naturally-contaminated feed. Food Additives and Contaminants, 17: 2, $167-175$.

Groopman, J.D. and Kensler, T.W. (2005). Role of metabolism and viruses in aflatoxin-induced liver cancer. Toxicology Application of Pharmacology, 206 (2):131-137.

Harvey, R.B., Kubena, L.F. and Phillips, T.D. (1993). Evaluation of aluminosilicate compounds to reduce aflatoxin residues and toxicity to poultry and livestock: A Review Report: Science Total Environment, 3-1457.

Hassan, A. (2003) Effect of feeding contaminated diet with aflatoxin on performance, milk yield and blood biochemical characteristics of lactating ewes. Egyptian Journal Nutrition and Feeds, 6 (Special Issue):1253-1265.

McNitt, J.I. and Lukefahr, S.D. (1990). Effects of breed, parity, day of lactation and number of kits on milk production of rabbits. Journal of Animal Science, 68, 1505- 1512.

Meshreky, Samia Z., Arafa, Mervat M., Abo Warda, M.A. and Gad Alla, S.A.Z. (2007). Male and female rabbits performance traits as affected by dietary aflatoxin contamination and its detoxification. Egyptian Journal of Rabbit Science, 17 (1): $27-42$.

Mills, T.M. and Stopper, V.S. (1989). The intraovarian progesterone modulation of follicle development in the rabbit ovary. Steroids, 54: 471-480. 
Nowar, M.S., Abd Ei-Rahim, M.I., Tawfeek, M.I. and Zenate A. Ibrahim (2001). Effect of various levels of Egyptian Raw tafla on detoxification of rabbits diet naturally contaminated with aflatoxins. Egyptian Journal Nutrition and Feeds, 4 (Special Issue): 845-860.

NRC. (1984). Nutrient Requirements of Rabbits. 3ed Washington: National Academic Press, 30 pp.

Parr, R.A., Cumming, I.A. and Clarke, I.J. (1982). Effects of maternal nutrition and plasma progesterone concentrations on survival and growth of the sheep embryo in early gestation. Journal of Agricultural Science, Cambridge, 98: 3946.

Ramos, A.J. and Fernandez, E. (1993). Resin colestiramina: un adsorbente de zeralenona de alta afinidad. Proc. XIV Congreso Nacional de Microbiologia, 8-11 September, Zeragoza, Spain.

SAS (1996). User's Guide: Statistics, Version 6.12 Edition. SAS Institute, Cary, NC.

Schatzmayr, G., Zehner, F., Taubel, M., Schatzmayr, D., Klimitsch, A., Loibner, A.P. and Binder, E.M. (2006). Microbiologicals for deactivating mycotoxins. Mol Nutrition Research, 50(6):543-551.

Soliman, A.A.M., El-Saadany, S.A. and Maharem, G.M. (2005). Effect of different sources and levels of clays on growth and performance of sheep. Proc. $2^{\text {nd }}$ Conference Animal Production Research Insitute., Sakha 27-29 Sep.:119-136.

Soliman, K.M., El-Faramawy, A.A., Zakaria, S.M. and Mekkawy, S.H. (2001). Monitoring the preventive effect of hydrogen peroxide and gamma-radiation of aflatoxicosis in growing rabbits and the effect of cooking on aflatoxin residues. Jounal of Agriculture Food Chemistry, 49(7):3291-3295.

Veldman, A., Meijst, J.A., Borggreve, G.J. and Heeres-van der Tol, J.J. (1992). Carry-over of aflatoxin from cows food to milk. Animal Production, 55:163168.

Winston, M. and Hagler, J. (1988). An Epidemiological Investigation Associating aflatoxin M1 with milk production in dairy cattle. Veterinary Human Toxicolygy,30:1.

Zerrouki, N., Berchiche, M., Bolet, G. and Lebas, F. (2002). Study of prolificacy and its components in a local Kabilian rabbits population in Algeria. 3rd Sci Conf on Rabbit Production in Hot Climates, Egypt; 375-382. 


\section{تأثير مصادر الطين المعدني على الأداء التناسلي لإناث الأرانب المغذاة على علائق ملوثنة بالأفلاتوكسين الإنابن}

سامية زكريا مشرقي ، صلاح عبد الحكيم ذكى جاد الله، محمد أنور أبو ورده، مرفت محمود عرفة معهد بحوث الإنتاج الحيو اني- مركز البحوث الزراعيةـ وزارة الزراعة.

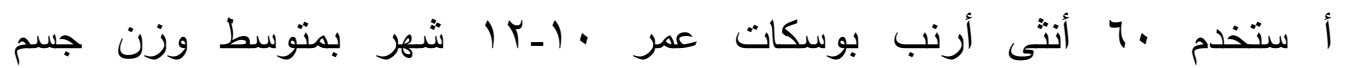

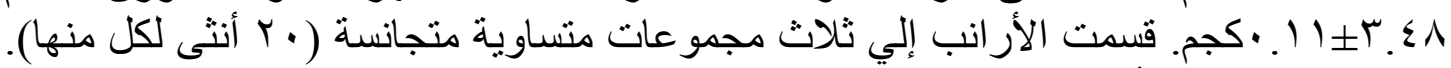

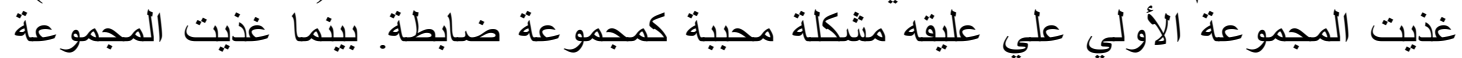

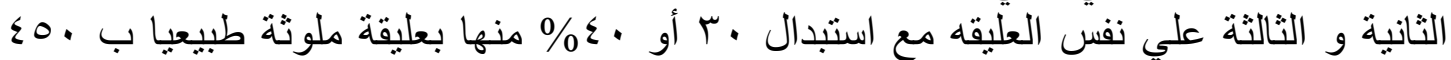
جزء في البليون (أفلاتوكسين

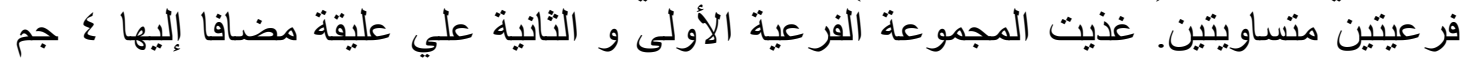

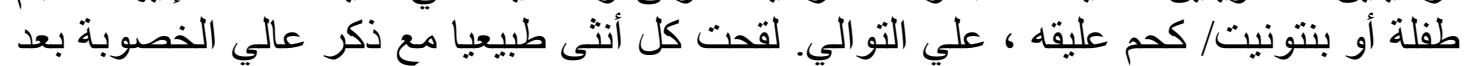

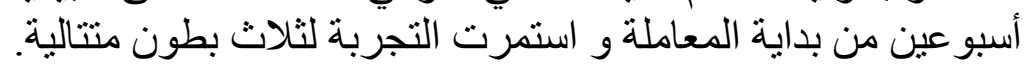

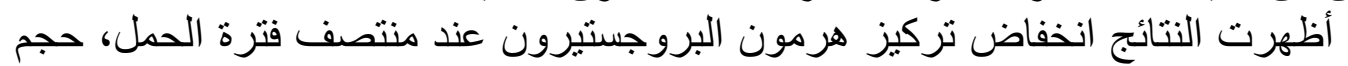

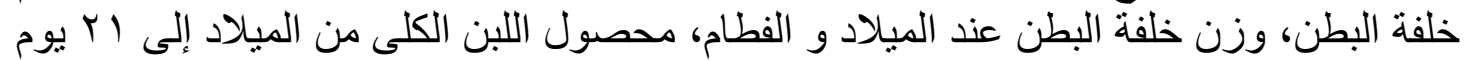

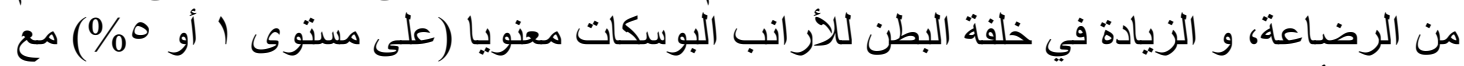

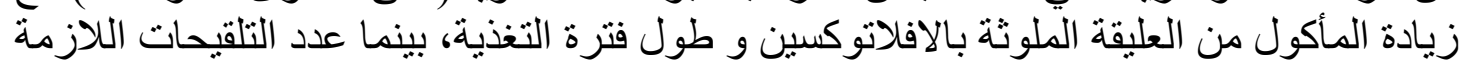

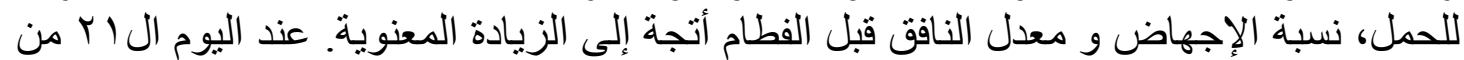

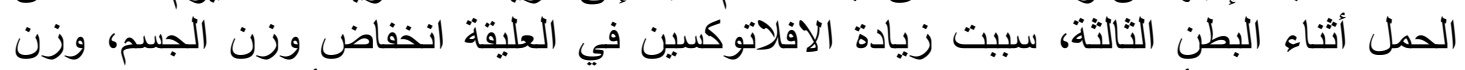

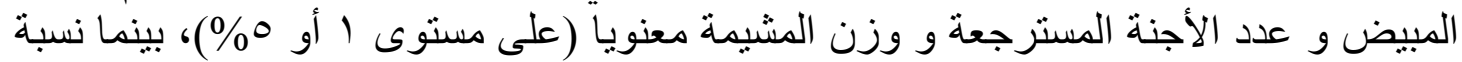

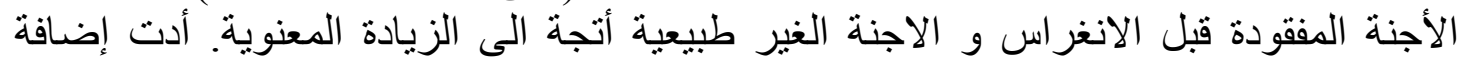

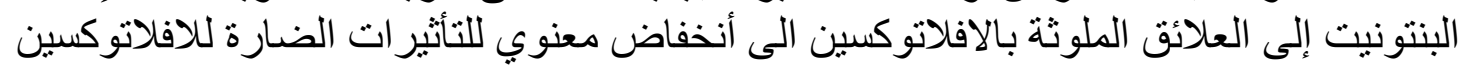

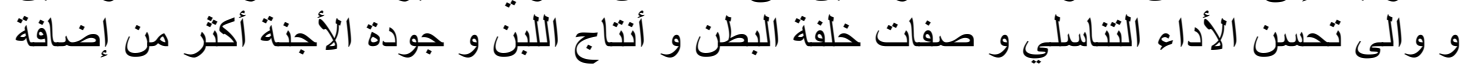

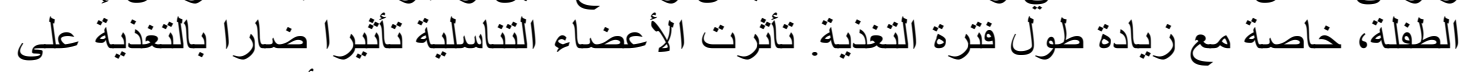

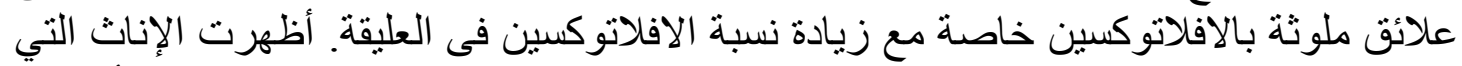

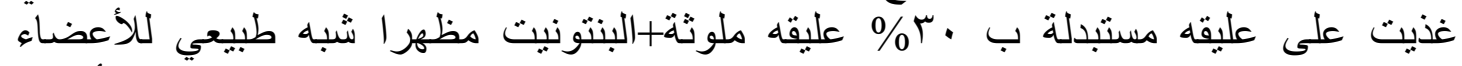

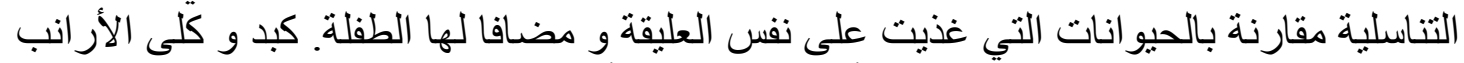

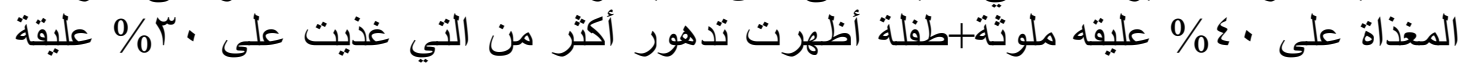

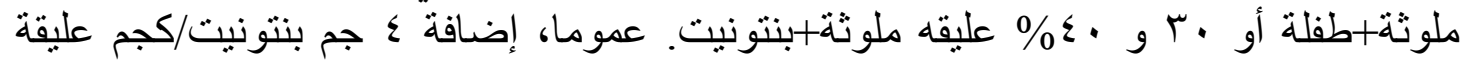

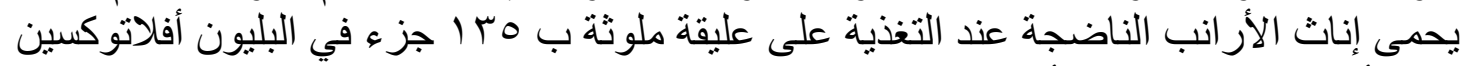
بدون أعاقة في النشاطو الأداء التناسلي. 